\title{
Relationship between Ownership Structure and the Modes of Dividend Payment: A Study on Dhaka Stock Exchange
}

\author{
Mohammad Ruhul Amin'; Md. Abdullahel Kafi²; \& Md. Mahabbat Hossain ${ }^{3}$
}

${ }^{1}$ Assistant Professor of Finance, Southeast University, Bangladesh

${ }^{2}$ Assistant Professor of Accounting, Northern University Bangladesh, Bangladesh

${ }^{3}$ Faculty Member, Bangladesh Institute of Bank Management (BIBM), Bangladesh

\begin{abstract}
This paper investigates whether percentage of ownership controlled by the directors of companies has any association with types of dividend declared by them. Based on the data for the years 2006 to 2009 from the Dhaka Stock Exchange, this paper found that most of the companies provided stock dividends rather than cash dividends. Using Yate's Continuity Correction Chi-square Test, this study has found existence of a significant relationship between the percentage control of ownership and types of dividend declared. Furthermore, the study indicates that the companies having $\geq 50 \%$ share controlled by the directors are 3 times more likely to offer stock dividends than companies having $<50 \%$ control of the shares by the directors. Whereas, the companies having $\geq 50 \%$ control of ownership by the directors are less likely to offer cash dividends compared with $<50 \%$ control of the shares by the directors.
\end{abstract}

Key Words: Dhaka Stock Exchange, Ownership Structure, Dividend Policy JEL Classification Code: G32; D78

\section{INTRODUCTION}

S hareholders are the owners of every corporation. However, every share holder is not concerned to voice out their opinion regarding the policies passed in AGM. They feel that their voices are insignificant related to the voting power of the directors who mostly hold a significant portion of the stocks. Thus, the corporate decision regarding to pay stock dividend or cash dividend is primarily made by the Board of Directors $(\mathrm{BoD})$ in their board meeting and most of the time the other small share holders unanimously agreed upon the decision in the annual general meeting (AGM). The question then arises whether cash or stock dividend benefits more to the majority shareholders, namely the BoDs of the corporation. This issue is important to the investors in general for making their investment decision so as to maximize their wealth. Furthermore, it is also relevant with the problem of agency cost involved for the firms, as the directors are not only the decision makers whether or not to provide any dividend by the firms but also are direct beneficiary of the applied dividend strategy.

A stock dividend implies an increase in nominal share capital and hence a decrease in retained earnings. Firms announcing stock dividends finance growth entirely by debt (explaining the need for an increase in nominal share capital) and retained earnings. The shareholder can keep the shares and hope that the company will be able to use the money not paid out in as cash dividend to earn a better rate of return, or the shareholder could also sell some of the new shares to create his or her own cash dividend. The biggest benefit of a stock dividend is that shareholders do not generally have to pay taxes on the value. Taxes do need to be paid, however, if a stock dividend has a cashdividend option, even if the shares are kept instead of the cash. The idea about the relevance of dividend on the value creation of a company goes back to Modigliani and Miller's (1961) dividend irrelevancy hypothesis, who argued that dividend policy has no effect on either the price of a firm's stock or its cost of capital. In a perfect world, the dividend policy is irrelevant to shareholders wealth. This proposition has laid solid theoretical foundation for the dividend policy, which at later stage, the economists have offered explanations in different ways about dividend payment, such as effect of taxes, dividend signaling, agency cost issues and transaction cost.

The idea that ownership structures whether or not affect the modes of dividend payment is one of the important fields of study in capital market around the globe. Studies done by various researchers on both the developed and developing capital market found interesting results. Louis T. W. Cheng, Hung-Gay Fung \& T. Y. Leung (2006), found that in many emerging financial markets, firms typically pay stock dividends rather than cash dividends. Since the opening up of Chinese capital markets during the early 90 's, it has been found that Chinese investors 
appear to favor stock dividend over cash dividends. There are many hypotheses explaining why firms pay out stock dividends. The signaling and retained earnings hypotheses, which are closely linked and relate stock dividends to a firm's good growth or investment potential, appear to be the leading contenders in explaining stock dividend policies of firms in the U.S. (Baker et al, 1995).

Thus, it is important to analyze correlation between the directors' control of the shares and the modes of dividend payment by the firms. It may suggest trading strategy that can be devised based on the nature of the relationship. For this, we have chosen an emerging market in Asia, namely the Dhaka Stock Exchange (DSE). An extensive search of literatures also justifies the need to do because there is a dearth study on this market on the subject matter.

\section{Research ObJectives}

The objective of this paper is to examine existing relationship between ownership structure and modes of dividend payment, while it will also try to find out industrywise dividend payment for the years 2006-2009. Specifically, the paper is going to examine whether the percentage of directors' ownership has an impact on the dividend declaration of companies under different industries. If any, what types of dividend (equity or cash) is relevant with the majority (or minority) ownership shareholders.

\section{LITERATURE REVIEW}

Qiao, Y. and Chen, Y. (2001) found evidence of positive statistical relationship between dividends and mix dividend policies of firms in Chinese stock markets. Their study showed that the market was not sensitive with cash dividends but was reactive to stock dividends. On the other hand, Chen, Wei et al (1999) Empirically analyzed the dividend policy of different companies listed in Shanghai Stock Exchange by method of Cumulated Abnormal Return (CAR) and studied the existence and character of the signaling effect of dividend policy. The study found different degrees of CARs resulted from different dividend policies. The CARs of right issues were higher than that of cash dividend but lower than that of the bonus issues. Kalay and Loewenstein (1985) found a strong positive relation between dividend changes and a firm's ability to generate future earnings and cash. Authors showed that dividend loses its information content in explaining firm's future performance when earning and earning related variables (such as earnings forecast) are released simultaneously. A new view is the tunneling perspective, which argues that cash dividends may be used as a tool to re-direct firm resources to benefit large shareholders and top management at the expense of minority shareholders. A number of studies explore the reason for and the impact of issuing stock dividends. Proposals to explain stock dividends include the signaling, trading range, liquidity, cash substitution, and retained earnings hypotheses. Foster and Vickrey (1978) reported that stock dividend generates positive abnormal returns on the declaration date rather than on the ex-date and that size is not a determinant of market reaction, supporting a signaling function of stock dividends. Authors report significant abnormal returns around the announcement of stock dividends, suggesting that stock dividend issue is a signal for future cash dividends, cash flows, and earnings. In an examination of responses from chief financial officers, Eisemann and Moses (1978) found them supporting for signaling, liquidity, cash substitution, or retained earnings hypotheses. Whereas, Baker and Philips (1995) reported evidence from a managers' survey supporting signaling and retained earning hypotheses.

Cash dividends and stock dividends have been argued substitutes for one another. As discounting a dividend payment would likely produce a negative market reaction, firms usually issue stock dividends rather than paying out cash dividends that might lead to a cash shortage for internal use. Ghosh and Woolridge (1985) found that issue of stock dividends can mitigate the negative market reaction due to reduction or omission of cash dividends, which provides evidence for the cash substitution hypothesis. Fung and Leung (2001) proved that reinvestment by plowing back earnings should be viewed positively; as it indicates profitable opportunities in firms. If firms indeed have good investment prospects, shareholders prefer stock dividends in order to preserve cash for investments; seasoned equity financing is not readily available for future funding needs because of regulatory constraints in China. Thus, the underdevelopment of China's financial market implies that rational Chinese stockholders would generally prefer stock dividends to cash dividends, supporting the retained earning hypothesis. Huang and Fung (2004) found that if dividend policy serves as a signal to the market, firms' values (prices) will change as a result. Price appreciation will not translate into financial gains for the controlling stockholders whose shares cannot be traded through the stock exchanges. Thus, they would prefer cash dividend to realize an immediate financial gain. Mitton (2002) found no significant association between insider ownership and stock price performance for a sample of East-Asian companies. Furthermore, studies regarding the association between insider ownership and managerial misbehavior are found to have mixed results. Recent studies on the relationship between dividend policy and level of ownership by the directors include Wang (2006), Lee J. (2006) and Andres, C. (2008). Wang provided evidence that family ownership is associated with higher earning quality, a finding consistent with the alignment effect of family ownership. Jim Lee (2006) studied on S\&P and fortune 500 companies where a comparison based on net profit margin, employment, revenue and gross income growth were made between 1992-2000 and found that average profit margin for family firms was $10 \%$, two points higher than non-family owned 
Asian Business Review, Volume 4, Number 1/2014 (Issue 7)

ISSN 2304-2613 (Print); ISSN 2305-8730 (Online)

firms. German researcher Andres, C. (2008), analyzed on 275 German public companies and found that companies with significant family ownership are more positively and outperform their peers with other type of shareholders.

\section{Methodology}

To investigate the relationship between the ownership structure and the types of dividend payment by various companies, study years have been considered from 2006 to 2009. For this paper we have selected data on dividend payout by firms under different industries listed on Dhaka Stock Exchange (DSE). Survey years 2006 to 2009 have been selected because during these years many companies offered both cash and stock dividends for their shareholders and the related data have been collected from the official website of DSE (www.dsebd.org). A total of 193 samples have been selected from four different industries, namely, banks, insurance, cement, and pharmaceutical. Purpose sampling technique has been followed in this regard. The companies which declared either stock or cash dividends only are selected and companies which declared both stock and cash dividends are excluded from the sample of this study. The paper divided the firms into two main categories based on the control of the ownership by the directors of the companies. On one segment, there are companies with greater than or equal to $50 \%$ ownership controlled by the directors and on the other are the companies with less than $50 \%$ control of shares by the directors. Seventy one companies have been included in the survey having greater than or equal to $50 \%$ ownership by the directors whereas, 122 companies with ownership control of less than $50 \%$ by the directors.

The study begins with descriptive analysis of dividend payments by the four different types of industries for the study periods. Besides, the paper will also analyze whether the types of dividend declared has any association with the amount of control by the director shareholders for the selected sample. To analyze it the following hypotheses have been proposed:

$\mathrm{H}_{0}$ : There is no significant association between ownership structure and types of dividend payment.

$H_{1}$ : There is a significant association between ownership structure and types of dividend payment.

Chi-square $\left(x^{2}\right)$ test will be used to determine the significance of the association, if there is any. The greater the value of $x^{2}$, the greater would be the discrepancy between observed and expected frequencies. The formula for computing chi-square is:

$$
\begin{aligned}
& x^{2}=\sum \frac{(O-E)^{2}}{E} \\
& \text { Where, } \mathrm{O}=\text { observed frequency. } \\
& \mathrm{E}=\text { expected or theoretical frequency. }
\end{aligned}
$$

The calculated value of $x^{2}$ is compared with the tabulated value of $x^{2}$ for given degrees of freedom at specified level of significance. If the calculated value of $x^{2}$ is greater than the tabulated value, the difference between theory and observation is considered to be significant, i.e., it could not have arisen due to fluctuations of simple sampling. On the other hand, if the calculated value of $x^{2}$ is less than the table value, the difference between theory and observation is not considered significant, i.e., it could have arisen due to fluctuations of sampling. Logistic regression has also been used where ownership structure is considered as the independent variable and modes of dividend payment as the dependent variable.

\section{FINDINGS}

Table 1 describes the weighted average returns classified under the stock and cash dividends for the years 2006-2009 for the four selected industries. It shows that except for the year 2006, all the banks either provided stock dividends or a combination of both cash and stock since the firms which provided both types of dividends are excluded from our sample. During the year 2006 most of the banks provided stock dividends rather than cash dividends. With the exception of the year 2009, insurance companies provided mostly stock dividends where as cement and pharmaceutical industries provided mostly cash dividends. The reason for this could be primarily attributed to implementation of BASEL II, which made it obligatory that every commercial bank, insurance companies and other non-bank financial institutions have to increase the equity participation by issuing right/bonus shares for its shareholders and not primarily relying on the debt capital.

Table 1: Average Dividends of the Sample Companies for the Years 2006-2009 (\%)

\begin{tabular}{|l|cc|cc|cc|cc|}
\hline \multicolumn{1}{r|}{ Year \& Div. } & \multicolumn{2}{|c|}{2006} & \multicolumn{2}{c|}{2007} & \multicolumn{2}{c|}{2008} & \multicolumn{2}{c|}{2009} \\
\cline { 2 - 9 } Industry & Stock Cash & Stock Cash & Stock Cash & Stock Cash \\
\hline Bank & 28.08 & 25 & 54.98 & 0 & 29.05 & 0 & 32.22 & 0 \\
Insurance & 20.49 & 13.8 & 20.91 & 10.16 & 22.76 & 9.37 & 19.90 & 25 \\
Cement & 0 & 25.66 & 0 & 19.75 & 10 & 24 & 0 & 0 \\
Pharmaceutical & 15 & 24.07 & 0 & 34.24 & 0 & 32.8 & 60 & 58.75 \\
\hline
\end{tabular}

Source: Study result

Table 2 and 3 explain the average returns for both directors controlled firms $(50 \%$ or more controlled by the directors) and the general investors controlled firms (less than $50 \%$ controlled by the directors) and associated average dividends as stock and cash dividend. They show an interesting result. We find that higher percentage of stock dividends were declared for banks where the majority shares are controlled by the directors for the year 2007. But, for the year 2006, 2008 and 2009 companies with directors holding minority shares provided higher percentage of dividend. For insurance companies we find 
very similar dividend rates irrespective of the percentage control by the directors of the firms. For cement industry, cash dividends were mainly declared and the higher percentage of dividends went to the companies with primarily under the directors' control. However, pharmaceutical industry declares mainly cash dividends, where companies with less than $50 \%$ controlled by the shareholders during the years 2006, 2007 and 2009. Nevertheless, it has been changed during 2008 when a little larger dividend was declared for the favor of directors' controlled shares.

Table 2: Comparison of Average Dividends for $\geq 50 \%$ \& $<50 \%$ Control of Ownership by Directors in $2006 \& 2007$.

\begin{tabular}{|c|c|c|c|c|}
\hline \multirow{4}{*}{ Year/Div. } & \multicolumn{2}{|c|}{ Year-2006 } & \multicolumn{2}{|c|}{ Year-2007 } \\
\hline & Stock & Cash & Stock & Cash \\
\hline & \multicolumn{2}{|c|}{$\begin{array}{l}\text { Directors Control } \\
\text { of Ownership }\end{array}$} & \multicolumn{2}{|c|}{$\begin{array}{c}\text { Directors Control } \\
\text { of Ownership }\end{array}$} \\
\hline & $=50 \%<50 \%$ & $=50 \%<50 \%$ & $=50 \%<50 \%$ & $=50 \%<50 \%$ \\
\hline Bank & $26 \% \quad 29.8 \%$ & $25 \%$ & $74.97 \% 38.3 \%$ & $0 \%$ \\
\hline Insur ance & $17.3 \%$ & $13.8 \%$ & $20.64 \% \quad 21 \%$ & $8.78 \%$ \\
\hline Cement & $0 \%$ & $26 \%$ & $0 \%$ & $27.5 \% \quad 11.25 \%$ \\
\hline Pharmaceutica & $15 \%$ & $19.37 \% 30.33 \%$ & $0 \%$ & $24.37 \% \quad 54 \%$ \\
\hline
\end{tabular}

Source: Study result

Table 3: Comparison of Average Dividends for $\geq 50 \% \&$ $<50 \%$ Control of Ownership by Directors in 2008 \& 2009

\begin{tabular}{|c|c|c|c|c|c|c|c|c|}
\hline \multirow[b]{3}{*}{ Industry } & \multicolumn{4}{|c|}{ Year-2008 } & \multicolumn{4}{|c|}{ Year-2009 } \\
\hline & \multicolumn{2}{|c|}{ Stock } & \multicolumn{2}{|c|}{ Cash } & \multicolumn{2}{|c|}{ Stock } & \multicolumn{2}{|c|}{ Cash } \\
\hline & \multicolumn{4}{|c|}{$\begin{array}{c}\begin{array}{c}\text { Directors Control } \\
\text { of Ownership }\end{array} \\
\end{array}$} & \multicolumn{4}{|c|}{\begin{tabular}{|c|}
$\begin{array}{c}\text { Directors Control } \\
\text { of Ownership }\end{array}$ \\
\end{tabular}} \\
\hline & $=50 \%$ & $<50 \%$ & $=50 \%$ & $<50 \%$ & $=50 \%$ & $<50 \%$ & $=50 \%$ & $<50 \%$ \\
\hline Benk & $26.49 \%$ & $30.7 \%$ & $0 \%$ & $0 \%$ & $29.98 \%$ & $34.75 \%$ & $0 \%$ & $0 \%$ \\
\hline Insurance & $21.11 \%$ & $22.7 \%$ & $20 \%$ & $7.6 \%$ & $16 \%$ & $20.77 \%$ & $0 \%$ & $25 \%$ \\
\hline Cement & $0 \%$ & $10 \%$ & $24 \%$ & $0 \%$ & $0 \%$ & $0 \%$ & $36.5 \%$ & $\infty \%$ \\
\hline Pharmacestical & $\infty 6$ & $0 \%$ & $34.75 \%$ & $25 \%$ & $\infty \%$ & $60 \%$ & $58.75 \%$ & $58.75 \%$ \\
\hline
\end{tabular}

Source: Study result

Table 4 shows that out of the 193 sample companies for the four years a total of 135 companies provided only stock dividends where as 58 companies provided only cash dividends. Whereas, a total of 91 companies having $<50 \%$ ownership control by the directors offered stock dividend and 31 companies offered cash dividends. The same tendency has been observed in case of $\geq 50 \%$ control of ownership. In such case 44 companies declared stock dividend and 27 companies declared cash dividend.

Table 4: Four years average ownership structure and dividend category

\begin{tabular}{|c|c|c|c|}
\hline $\begin{array}{c}\text { Ownership } \\
\text { Structure }\end{array}$ & $\begin{array}{c}\text { Stock } \\
\text { Dividend }\end{array}$ & $\begin{array}{c}\text { Cash } \\
\text { Dividend }\end{array}$ & Total \\
\hline$<50 \%$ & 91 & 31 & 122 \\
\hline$\geq 50 \%$ & 44 & 27 & 71 \\
\hline Total & 135 & 58 & 193 \\
\hline
\end{tabular}

\section{Source: Study result}

Furthermore, to analyze the relationship between types of dividend declared and the ownership structure; a Yate's Continuity Correction chi square test was carried out since the number of degree of freedom is 1 and SPSS software has been used. The results of the Yate's Continuity Correction chi square test are shown in Table 5. It shows a significant relationship between types of dividend payment and the ownership structure at $\rho=10 \%$ level. Therefore, it can be concluded that the directors' control of ownership has significant association with the types of dividend paid, whether stock or cash.

Table 5: Results of Yate's Continuity Correction ChiSquare Test

\begin{tabular}{|c|c|c|}
\hline & Value & $\mathrm{df}$ \\
\hline Continuity Correction & 2.826 & 1 \\
\hline No. of Valid Cases 193 & & \\
\hline
\end{tabular}

Source: Study result

For a better understanding of the relationship a logistic regression has been run. The results of the logistic regression have been presented in Tables $6 \& 7$. Where, $<50 \%$ ownership controlled by directors is indicated as 0 (zero) and $\geq 50 \%$ ownership controlled by directors is indicated as 1 (one). Table 6 indicates that companies having $\geq 50 \%$ control of ownership by directors are less likely to offer cash dividends than stock dividends compared with $<50$ ownership controlled by the directors. Table 7 indicates that companies having $\geq 50 \%$ share controlled by the directors are about 3 times more likely to offer stock dividends than companies having $<50 \%$ control of the shares by the directors.

Table 6: Results of Logistic Regression

\begin{tabular}{|c|c|c|c|}
\hline $\begin{array}{c}\text { Ownership Controlled } \\
\text { by Directors }\end{array}$ & B & Sig. & $\begin{array}{c}\text { Exp(B)/Odd } \\
\text { s ratio }\end{array}$ \\
\hline$<50 \%$ & -1.077 & .000 & 1.000 \\
$\geq 50 \%$ & 0.341 \\
\hline
\end{tabular}

Source: Study result

Table 7: Results of Logistic Regression

\begin{tabular}{|c|c|c|c|}
\hline $\begin{array}{c}\text { Ownership Controlled } \\
\text { by the Directors }\end{array}$ & B & Sig. & $\operatorname{Exp}(\mathrm{B})$ \\
\hline$<50 \%$ & 1.077 & .000 & 1.000 \\
$\geq 50 \%$ & 2.935 \\
\hline
\end{tabular}

Source: Study result 


\section{CONCLUSION}

This paper has tried to investigate the relationship between director's control of ownership and modes of dividend payment. It found that, in general, most of the industries would like to provide stock dividend rather than cash dividend. Using Yate's Continuity Correction Chi-Square, this study has found existence of a significant relationship between the percentage control of ownership and types of dividend declared. Furthermore, the study indicates that companies having $\geq 50 \%$ control of ownership by directors are less likely to offer cash dividends than stock dividends compared with $<50$ ownership controlled by the directors. Whereas, the companies having $\geq 50 \%$ share controlled by the directors are about 3 times more likely to offer stock dividends than companies having $<50 \%$ control of the shares by the directors. This provides an intriguing thought on the matter of agency relationship. Whether or not the interests of the general investors are protected by the types of dividend declared is a matter of further study using longer time series data.

\section{REFERENCES}

Andres, C. (2008), "Large Shareholders and firm Performance: An empirical examination of founding-family ownership", Journal of Corporate Finance, 14 (4), 431-445.

Baker, H.K. and A.L.Philips, and G.E. Powell, (1995), "The Stock distribution puzzle: A Synthesis of the literature on stock splits and stock dividends", Financial Practice E Education, Spring/ Summer, 24-27.
Chen, W; Liu, X; Yang, Y; (1999), "An empirical study on the signaling effect of dividend policy in shanghais stock market", Chinese Journal of Management Science; 7(3).

Eisemann, P.C. and E. A. Moses, (1978), "Stock dividends: Management's view." Financial Analysts Journal 31, 77-80.

Foster, T. W. III and D. Vickrey, (1978), "The information content of stock dividend announcements," The Accounting Review 53, 360-370.

Fung, H G. and W.K. Leung, (2001) "Financial liberalization and corporate governance in china.", International Journal of Business, 2 (2), 3-31.

Ghosh, C. and J. R. Woolridge, (1988), "An analysis of shareholder reaction to dividend cuts and omission", Journal of Financial Research 11, 281-294.

Huang, A.G. and H.G. fung, (2004), "Stock ownership segmentation, floatability, and constraints on investment banking in china." China and world Economy, 12 (2), 66-78.

Kalay, A. and U. Loewenstein, (1985), "Predictable events and excess returns: the case of dividend announcements," Journal of Financial Economics 14, 149-175.

Lee, J. (2006), "Family Firm Performance: Further Evidence" Family Business Review. 19 (2), 103-114.

Merton H Miller, Franco Modiglian. (1961), “Dividend policy, growth, and the valuation of shares.", Journal of Business, 34:411-33.

Mitton, T. (2002). "A cross-firm analysis of the impact of corporate governance on the East Asian financial crisis". Journal of Financial Economics. 64: 215-241.

Qiao, Y; Chen Y; (2001), "Dividend policy and fluctuation of stock market in Chinese companies", Economic Research; 4 (in Chinese)

Wang, D (2006), "Founding Ownership and Earnings Quality", Journal of Accounting Research, Vol. 44, No. 3. 